\title{
Viejo Formation: A New Formation for the Imperial Group Sediments in the southern Coyote Mountains, Salton Trough, southern California.
}

\section{George J Morgan (georgemorgan@cox.net) and}

\section{JR Morgan, 4671 Lee Ave., La Mesa, Calif. 91942}

Kidwell and Winker (1996) describe the Andrade Member of the Latrania Formation, Imperial Group as a marine progradation (transgression) over the non-marine fanglomerate of their Garnet Formation, Split Mountain Group in the Coyote Mountains (CM). Our detailed mapping in the CM indicates that their Garnet Formation is composed of several (4+) distinct fresh-water fanglomerates. We also have divided their Andrade Member into several (8+) transgression-regressional (T-R) marine (Imperial Group) sequences that bracket some of our fresh-water fanglomerates. The transgressions have a recognizable, predictable and repeated marine sedimentary sequence consisting of a basal conglomerate followed by sandstone and then a mudstone. These marine sedimentary sequences are capped by unconformities representing regressions. Imperial marine sediments interfingers with one of our freshwater fanglomerates. Fresh water limestones are associated with at least two of our fanglomerates. Our fresh-water fanglomerates and T-R marine sequences make up our Viejo Formation (VF).

The lower part of the VF has a siltstone (Woodring's Outcrops [Morgan and Morgan, 2015]) that is interbedded with basalts of the Alverson Formation (17 Ma, Morgan et al., 2012). The youngest member of the VF has a distinctive basal conglomerate (Dark Cuesta Member [DCM]), described as having resistant, well-rounded, quartz rich pebbles in a course, granitic, arkosic matrix with granitic lithic fragments. The matrix and lithic fragments are responsible for the desert varnish that is often found on this member. We believe this youngest basal conglomerate may be, in part, reworked from a run out debris flow that came from an unidentified granitic terrane. When this basal conglomerate was being deposited, younger VF already covered the CM.

Winker and Kidwell (1996) describe the Latrania Formation as a marine turbidite section in a subsiding basin in the Fish Creek-Vallecito-Split Mountain area. The VF is made up of marine transgressions and regressions intermingling with fresh-water sediments deposited at sea level on the subsiding CM. An early part of the VF was deposited in the Basin and Range extensional environment when the CM were in the State of Sonora, 
Mexico. We believe there are enough differences between the Latrania and the VF to separate them. This would make Christensen's (1954) Garnet Formation, which is bracketed by T-R sequences, a member of the VF.

\section{Slide 1}

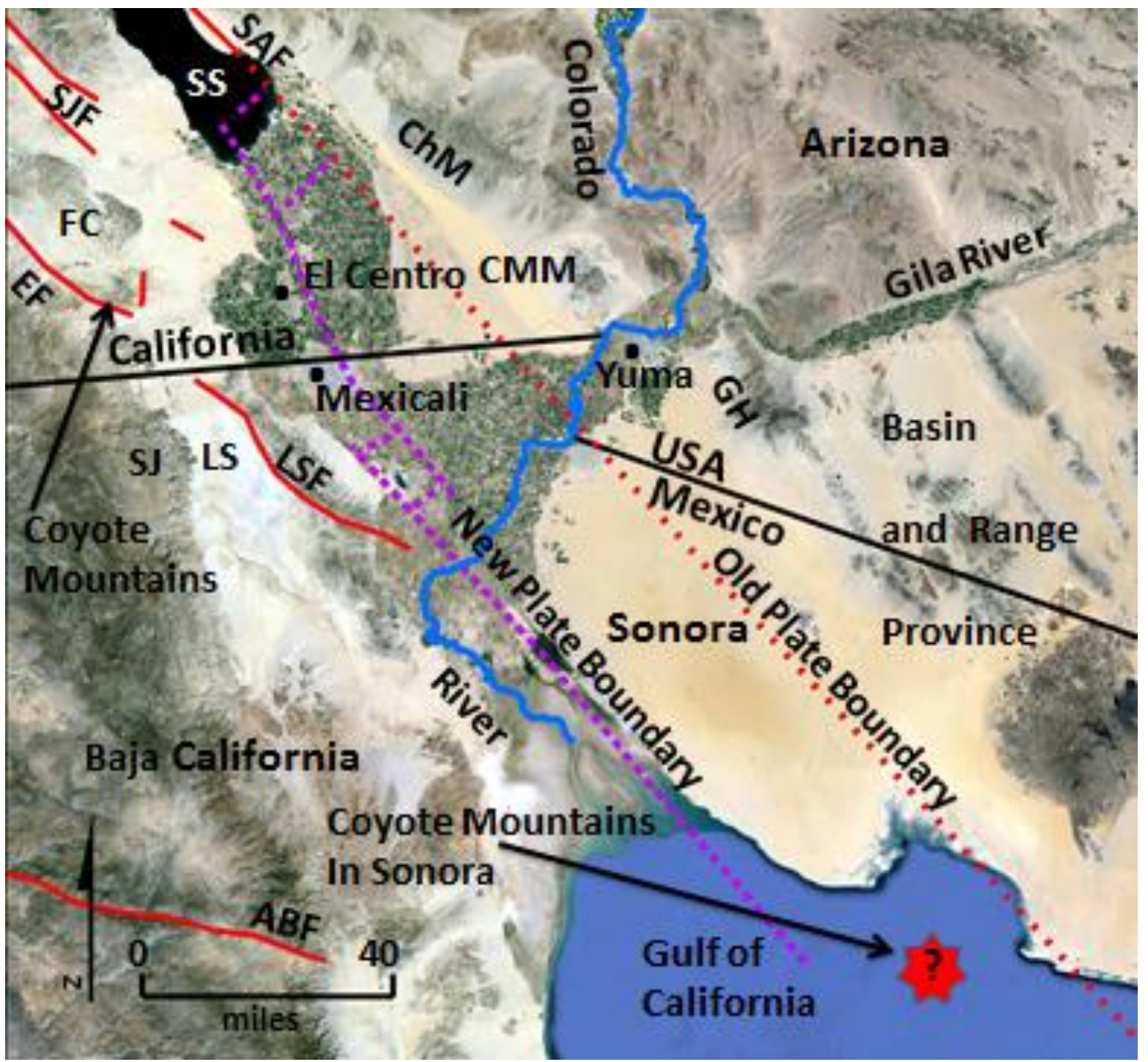

ABF-Agua Blanca Fault,CMM-Cargo Muchacho Mountains,ChM-Chocolate Mountains, EF-Elsinore Fault, FC- Fish Creek Mountains, GM-Gila Mountains, LSLaguna Salada, LSF-Laguna Salada Fault, SAF-San Andreas Fault, SJF-San Jacinto Fault, SJ-Sierra Juarez, SS-Salton Sea. Red star is the paleogeographic location of the Coyote Mountains 5.5 Ma by Winker and Kidwell (1996). We agree with their paleogeographic location for the CM. NASA photograph. 


\section{Slide 2}

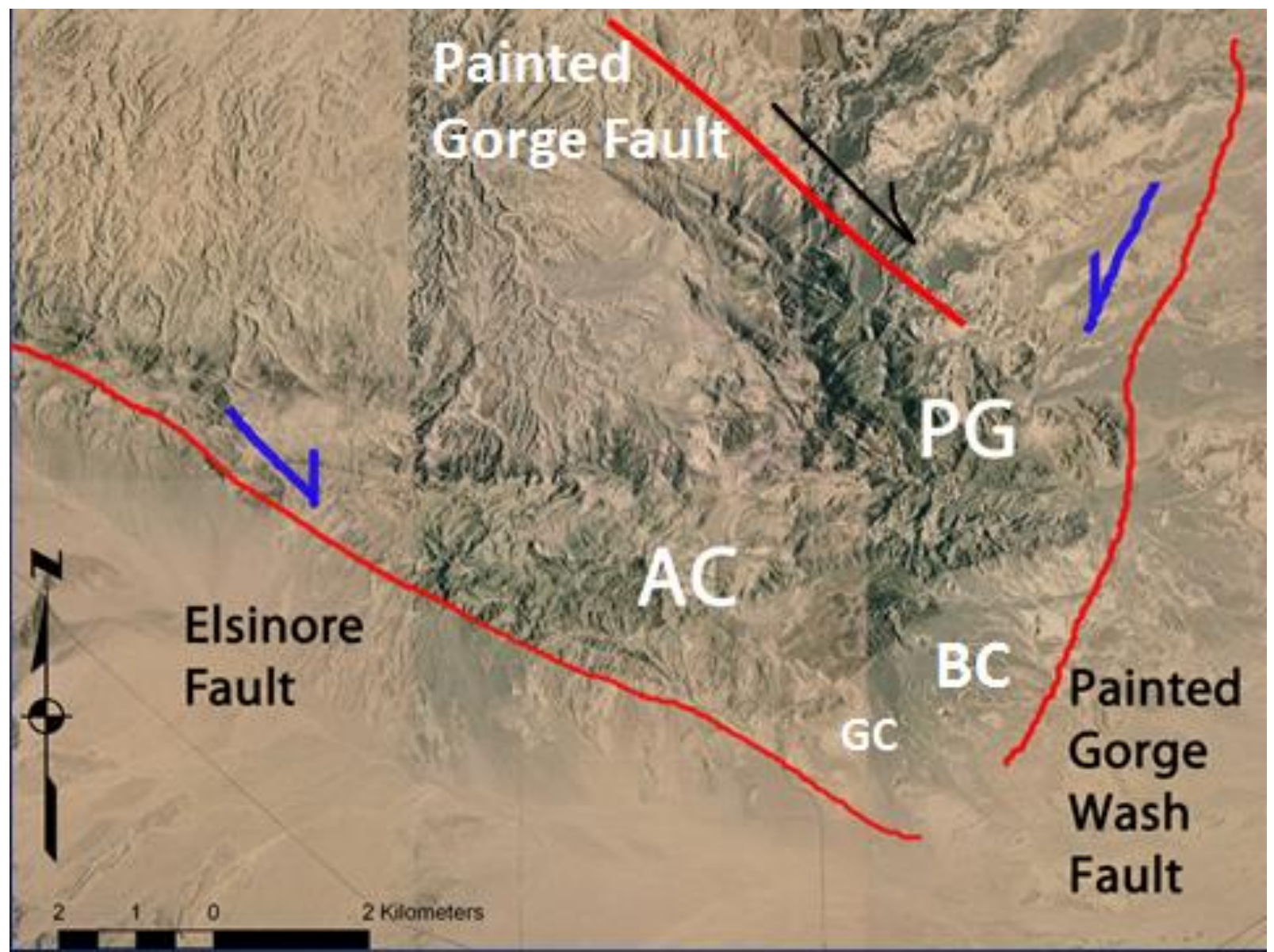

AC-Alverson Canyon or Fossil Canyon, PG-Painted Gorge, BC- Bataca Canyon, GCGypsum Canyon. We are mapping at 1:2,000 scale [using quality digital orthoquadrangles and ArcMap allows us to map at this scale]. Most of the authors before us mapped at smaller scales. Our mapping at this scale allows us to plot field relationships that would be impossible to place on maps with smaller scales. Painted Gorge Wash Fault (Morgan and Morgan, 1005). Painted Gorge Fault (Christensen, 1958). Elsinore Fault (Dibblee, 1954). 
Slide 3

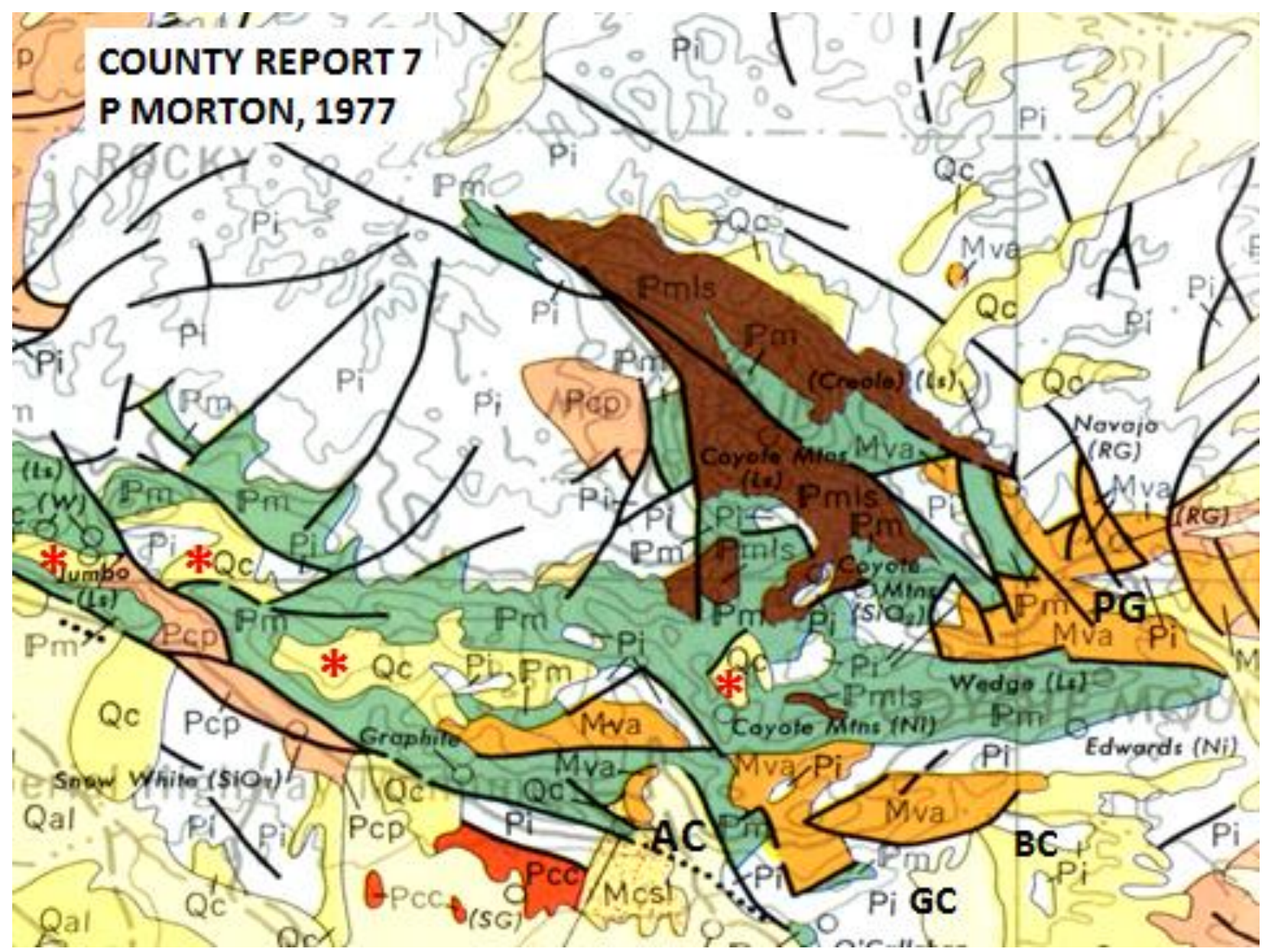

Morton's map is a good base to start with. He used both Dibblee (1954) and Christensen (1957) to make his map. Pm and Pmls-Paleozoic(?) marbles, schists, quartzites, cherts, amphibolites intruded by Jurassic igneous rocks (Morgan and Morgan, 2015). We have not found any Cretaceous igneous rocks yet. Mva- Miocene Alverson Formationbasaltic and hornblende indicate plugs, cinder cones, basaltic and andesitic basalt flows, lahars, tuffs, volcanic breccia, on top of continental sediments. Pi-Miocene to Pliocene Imperial Group marine sediments: Viejo Formation-marine transgressional-regressional sequences intermingled with fresh water fanglomerates, sandstones and limestones; Deguynos Formation-mudstones, siltstones, rhythmites, shell beds. Pcp and PacPliocene to Pleistocene Palm Spring Group-fresh water sandstones, pink muds and conglomerates. Qc- Quaternary fresh water gravels.

*- Christensen's Garnet Formation. 
Slide 4

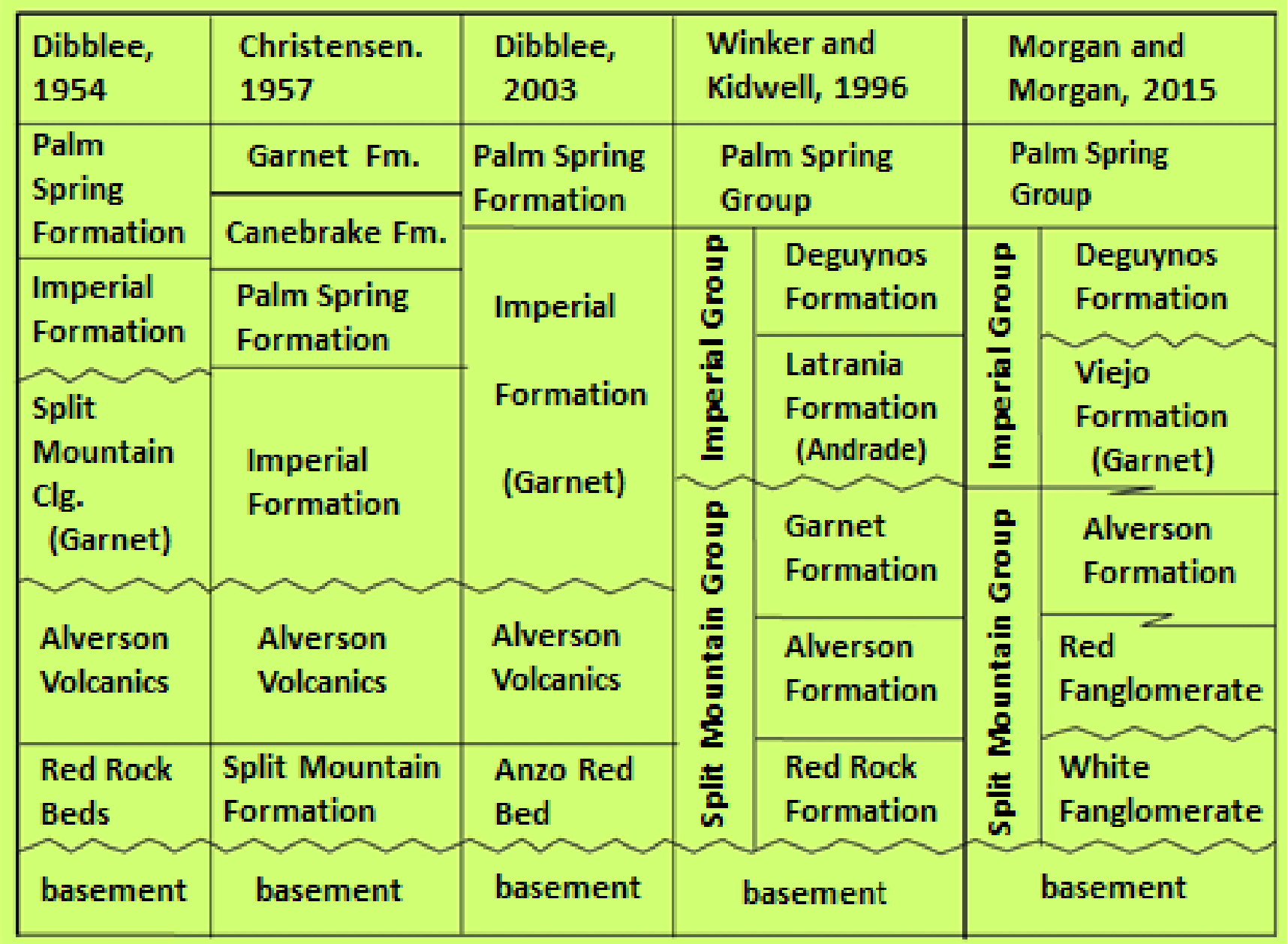

These geologists that have mapped large areas of the $\mathrm{CM}$ and their columnar sections are modified to showing just the units that are found in the CM. (Garnet)-designate units that contain Christensen's original Garnet. Note that the Garnet changes stratigraphic position depending on who mapped the unit. Winker and Kidwell's Garnet includes all the fanglomerates (4+) found in the CM. They describe the Garnet as having marine toes (interfingers?). Marine units are only found in the Imperial Group. Why is the Garnet in the Split Mountain Group and under the Latrania?

Winker and Kidwell's Latrania is a turbidite section found in Split Mountain area north of the $\mathrm{CM}$. There are no turbidites in the $\mathrm{CM}$ only marine mudstones, sandstones and conglomerates, thus their use of the name Andrade. Their Andrade Member represents only one transgression and all the marine sandstones in the CM. 


\section{Slide 5}

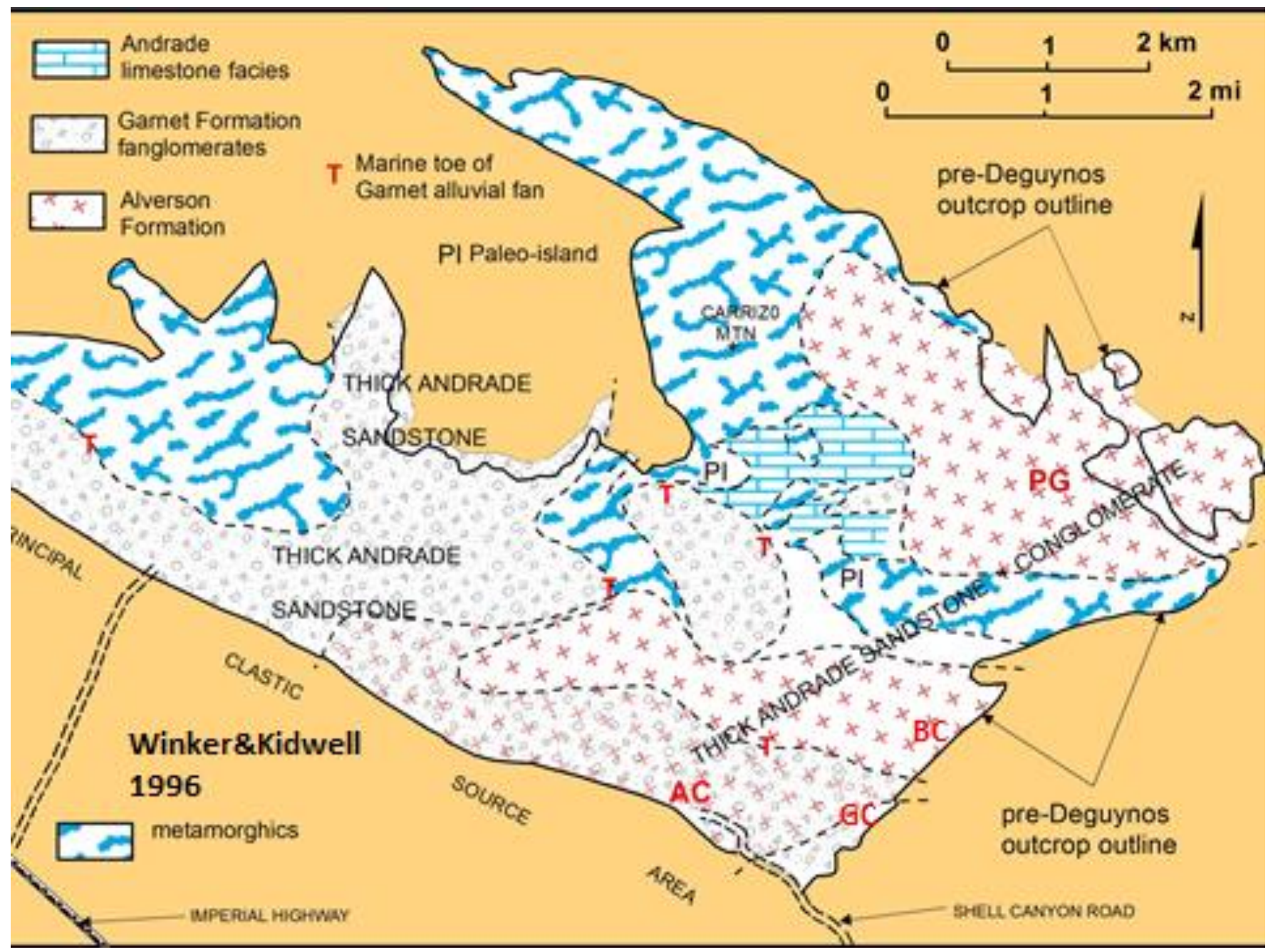

Winker and Kidwell's Andrade covered most of the CM except for the paleo-islands and the Carrizo Mountain area. Their Garnet Formation represents all the fanglomerates found in the CM above the Alverson Formation. At the Ts on the map, Imperial Group marine sediments are found on top of their Garnet Formation. What they did not map were areas where Imperial Group sediment interfinger with and are found under their Garnet. 
Slide 6

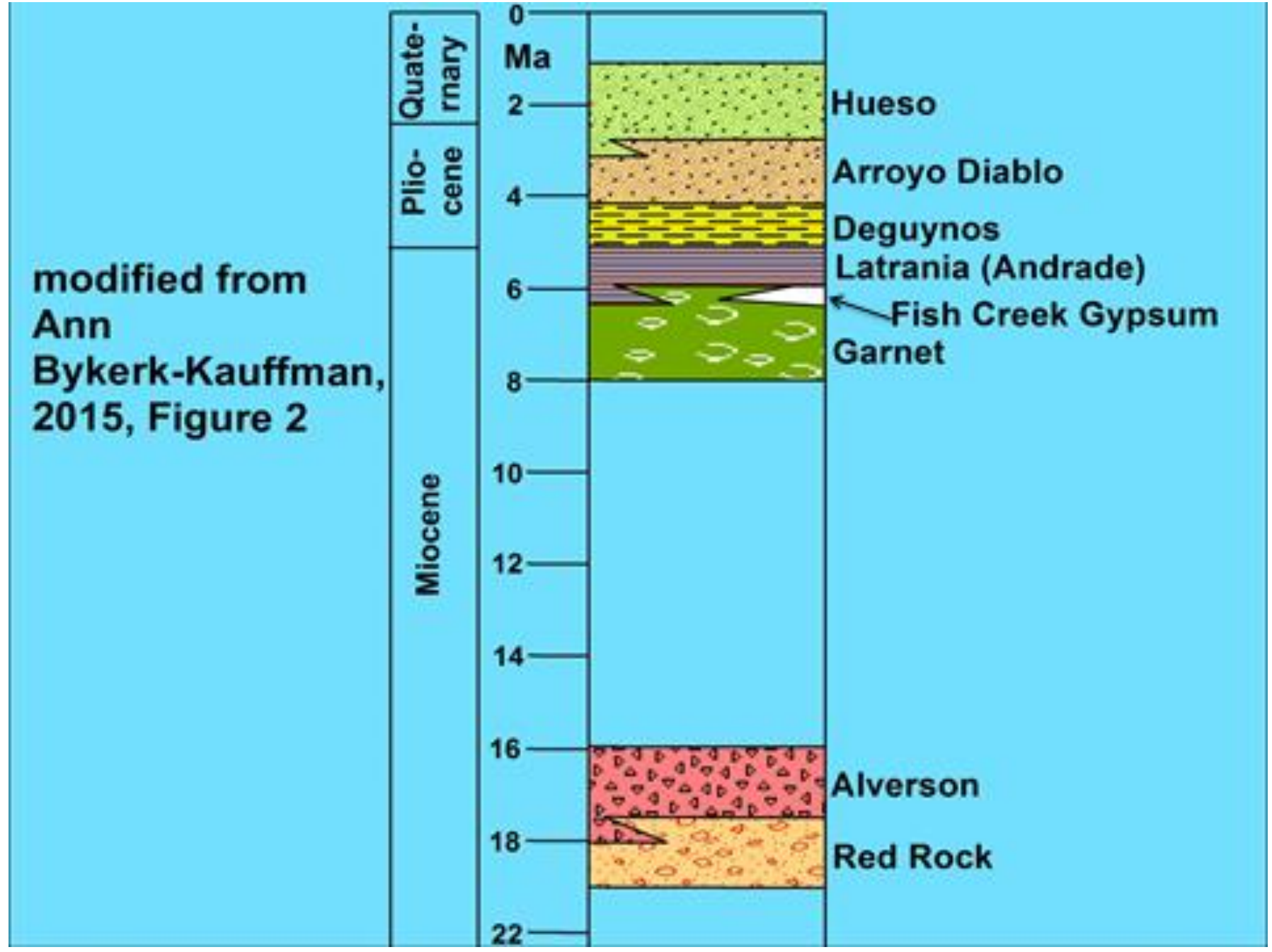

Bykerk-Kauffman and her students have been mapping the CM for 20 years using Winker and Kidwell's nomenclature. In this particular columnar section, BykerkKauffman does not show her Quaternary Ridge Graves (Christensen's Garnet). The Andrade Member sandstone of the Latrania Formation represents a single transgression and the Garnet represents all the fanglomerates found in the CM. 
Slide 7

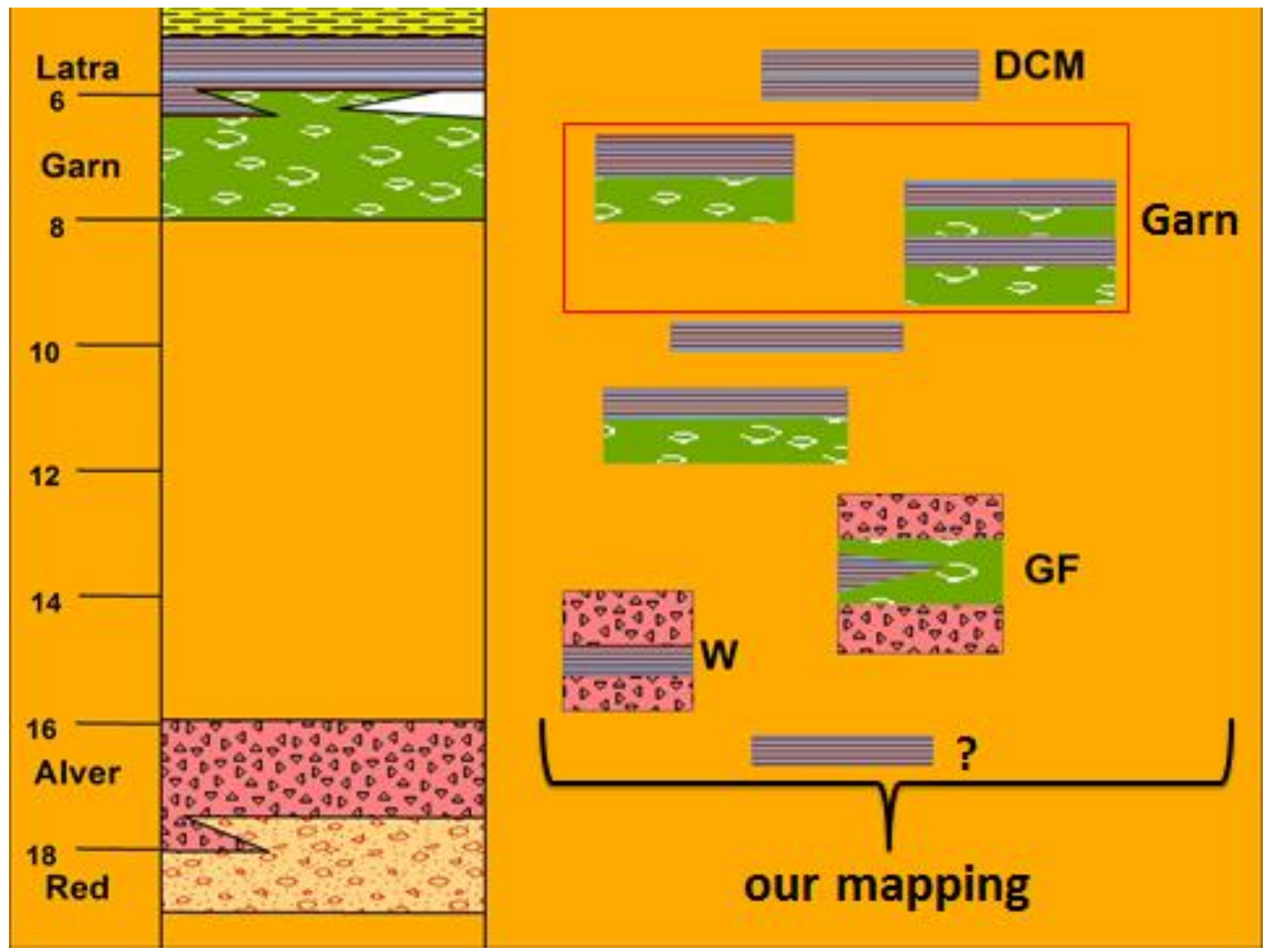

When we started mapping in the CM we used Winker and Kidwell's nomenclature, but our stratigraphy kept blowing up. It was not until we realized that there was more than one transgression and several regressions that our stratigraphy started to hold together. The red box is where we first mapped several T-R sequences and is the section with the greatest internal stratigraphic control. DCM- Dark Cuesta T-R Member(youngest). GarnChristensen's Garnet Formation and our Garnet T-R Member. GF-Green Fanglomerate T-R Member. W-Woodring T-R Member, We have mapped 8+ Transgression-Regressions $(T-R)$ and 5 fanglomerates. There is enough tectonic activity between transgressions that angular unconformities are formed between T-Rs. 
Slide 8

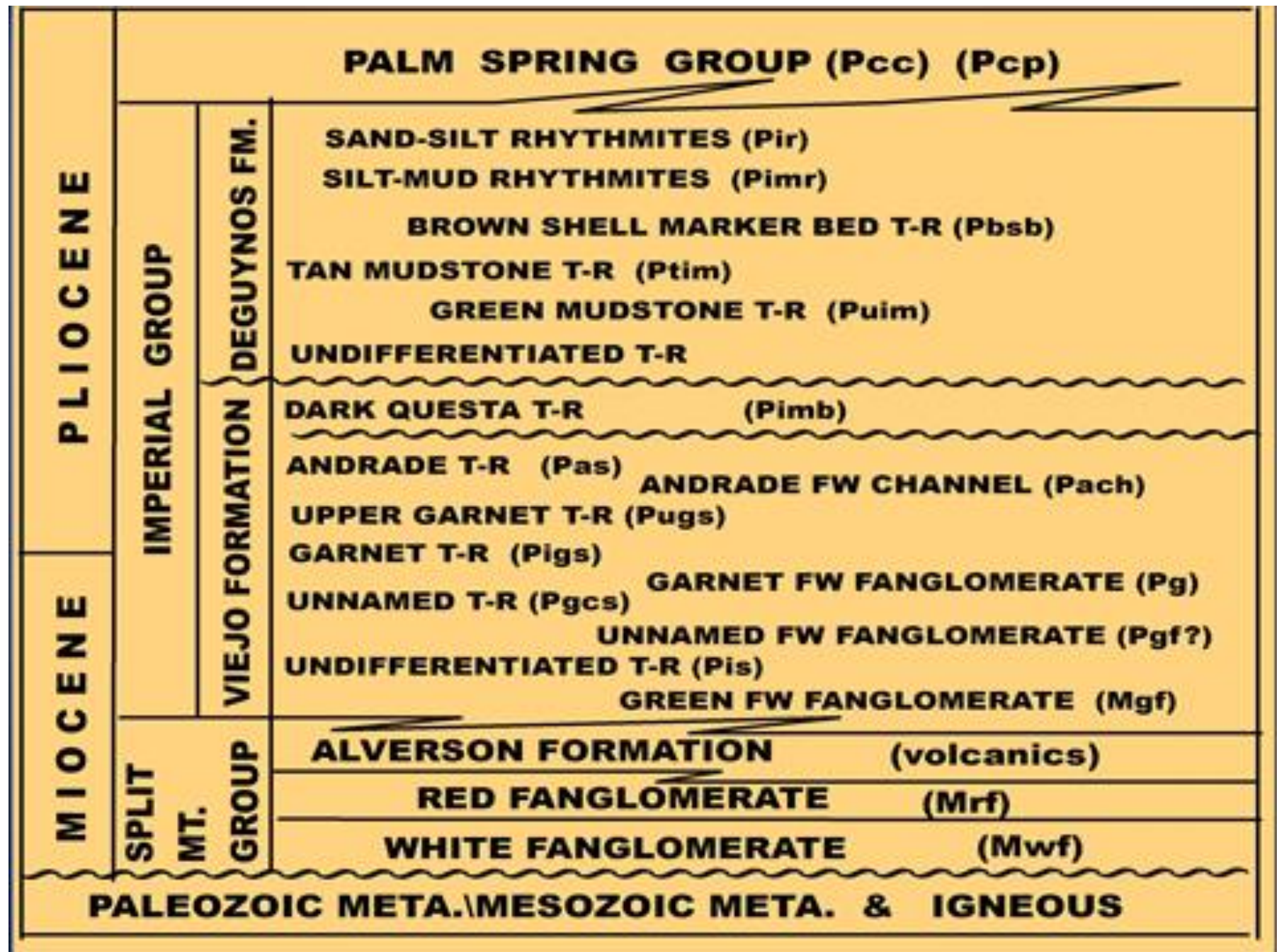

This is our working section for the Split Mountain and Imperial Groups. Note that we have the bottom of the Viejo Formation interfingering with the Alverson Formation and the Dark Cuesta as the youngest Viejo Member. 
Slide 9

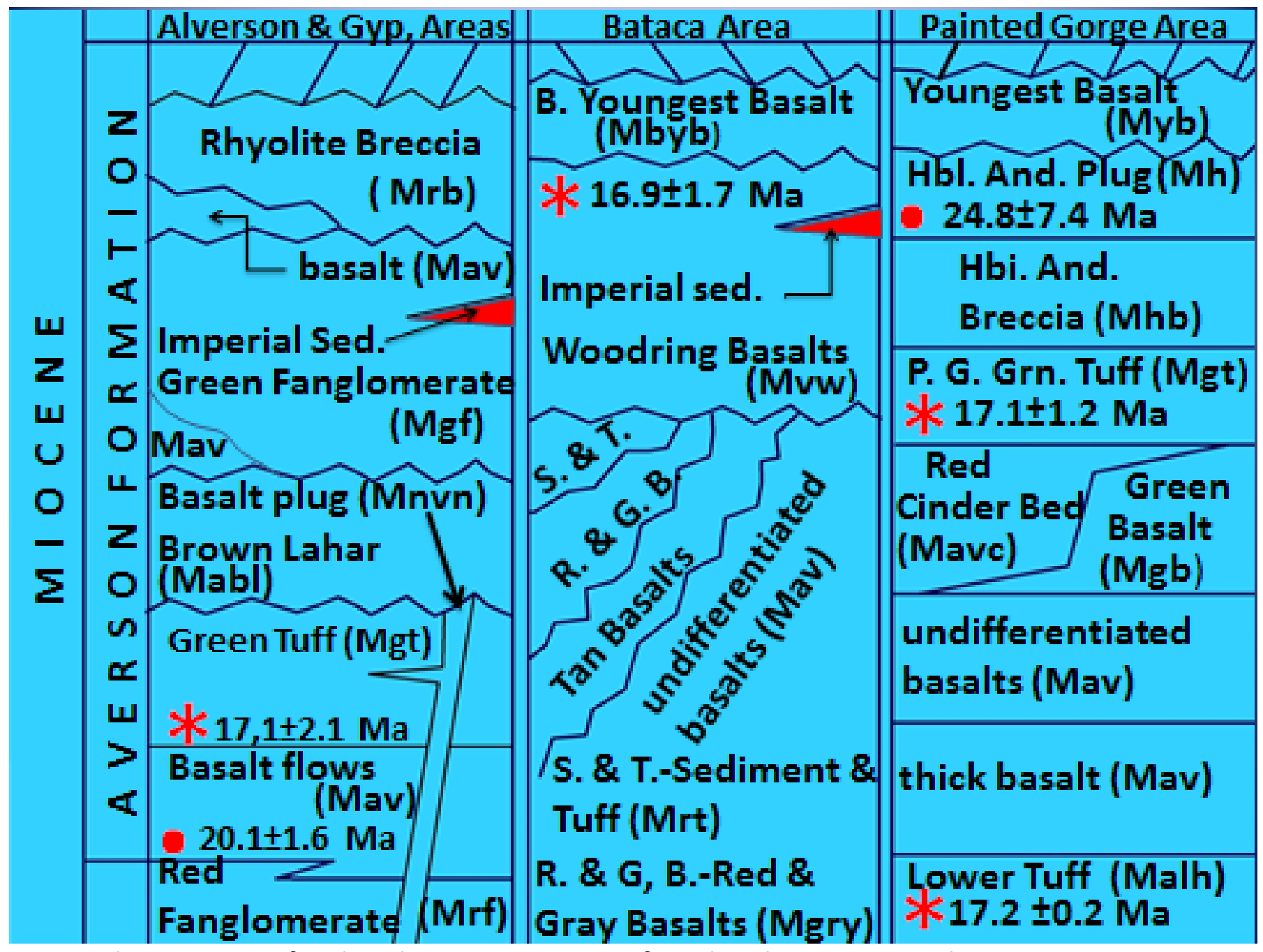

Our working sections for the Alverson Formation found in three areas in the $\mathrm{CM}$. We have yet to find a unit that correlates between these three areas. Note that Imperial Group sediments interfinger with the Alverson in two of the sections. Red asterisks indicate zircon age dates (Morgan and others, 2012). The 16.9 Ma (Morgan and Morgan, 2015) age for the Woodring Basalt flows is a detrital zircon date indicating that the Imperial Group sediments are younger than 16.9 Ma. Red boxes indicate K-Ar dates from Ruissard (1979). Hbl.- hornblende. And. - andesite.

In the CM, a typical T-R sequence has the following lithology: basal conglomerate, sandstone (calcarenite) followed by a mudstone. 
Slide 10

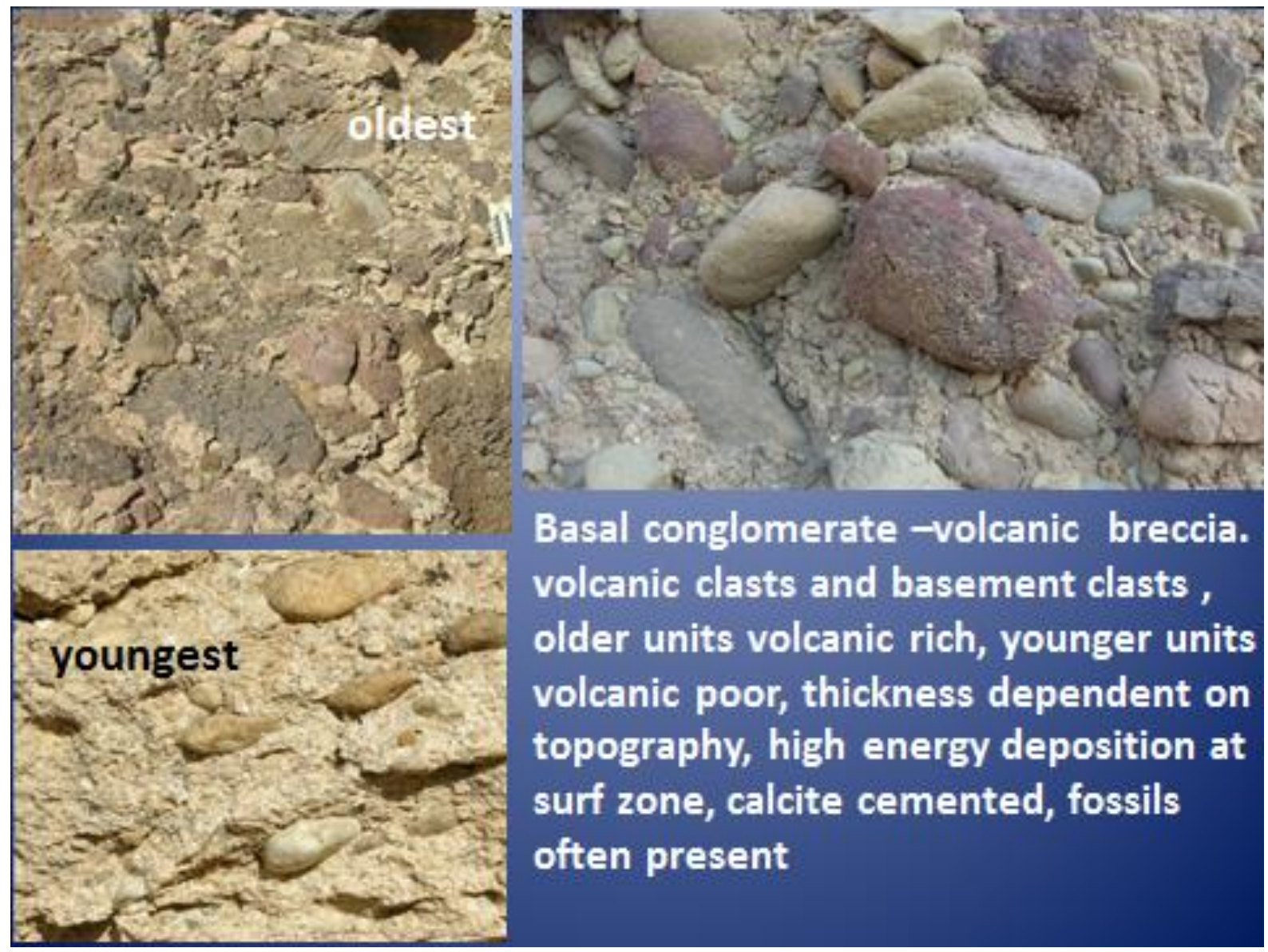

The basal conglomerates are the most distinctive part of the Viejo marine T-R sequences. The oldest conglomerates have breccia clasts made of only volcanic rocks from the Alverson Formation with calcarenite sand to silt matrix with poor bedding. The volcanic-breccia clasts range up to $2 \mathrm{~m}$ indicating that the environment of deposition was very energetic. The $\mathrm{CM}$ were not contributing metamorphic or granitic clasts to the oldest basal conglomerates indicating that the $\mathrm{CM}$, at one time, were completely buried by the Alverson. Younger basal conglomerates have rounded metamorphic, granitic and volcanic clasts. The youngest Viejo basal conglomerate contains quartz rich, reworked, pebbles in an arkosic granitic matrix. The lack of schist and marble cobbles indicate that the $\mathrm{CM}$ were not contributing to this T-R sequence and were probably buried completely by older units of the Viejo Formation. 
Slide 11

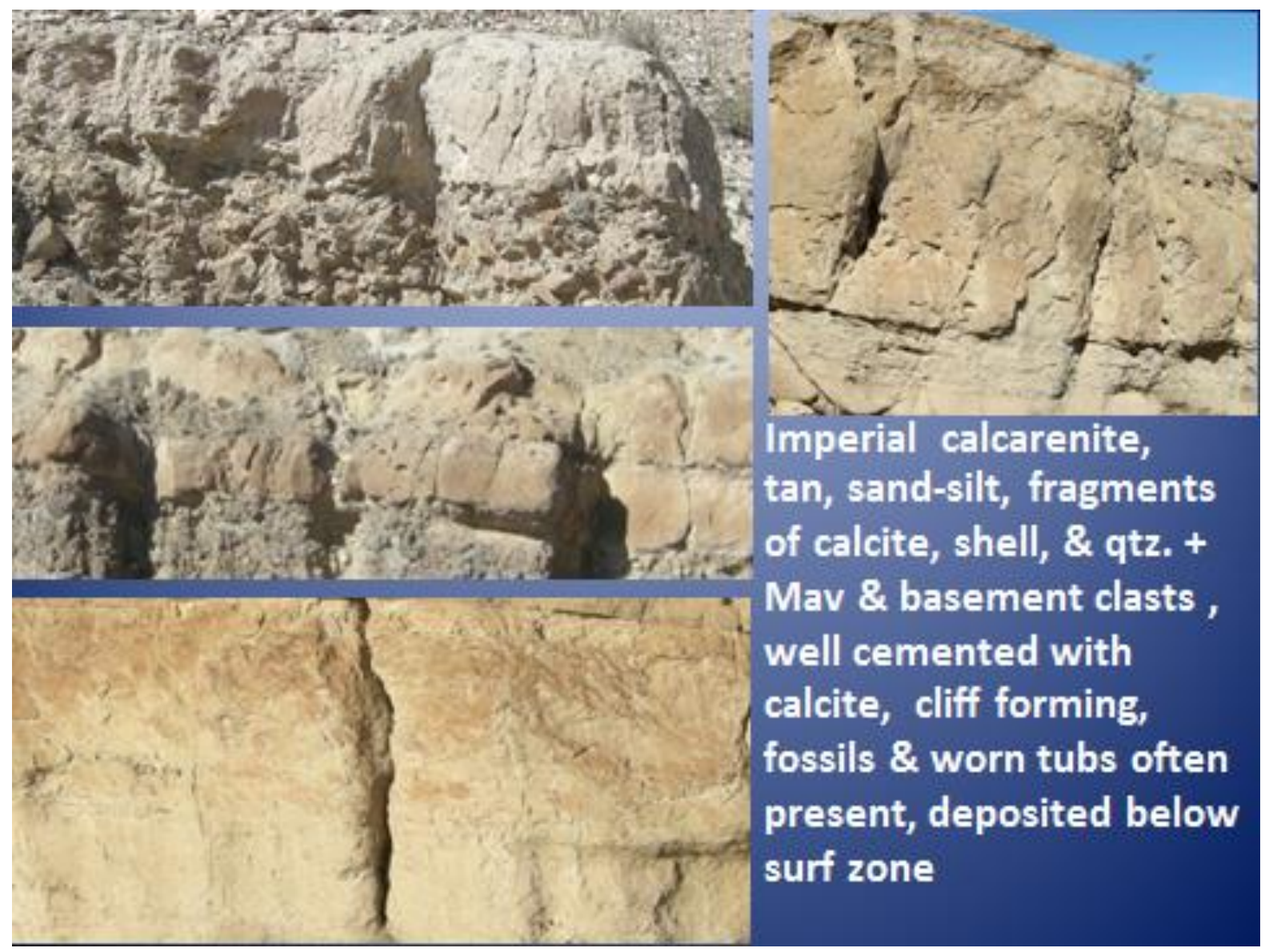

The sandstone parts of the T-R sequences are difficult to tell apart. They could be more correctly called calcarenite. They tend to be tan, massive with poor bedding, well cemented and cliff forming. Most of the sand size grains are calcium carbonate. 
Slide 12

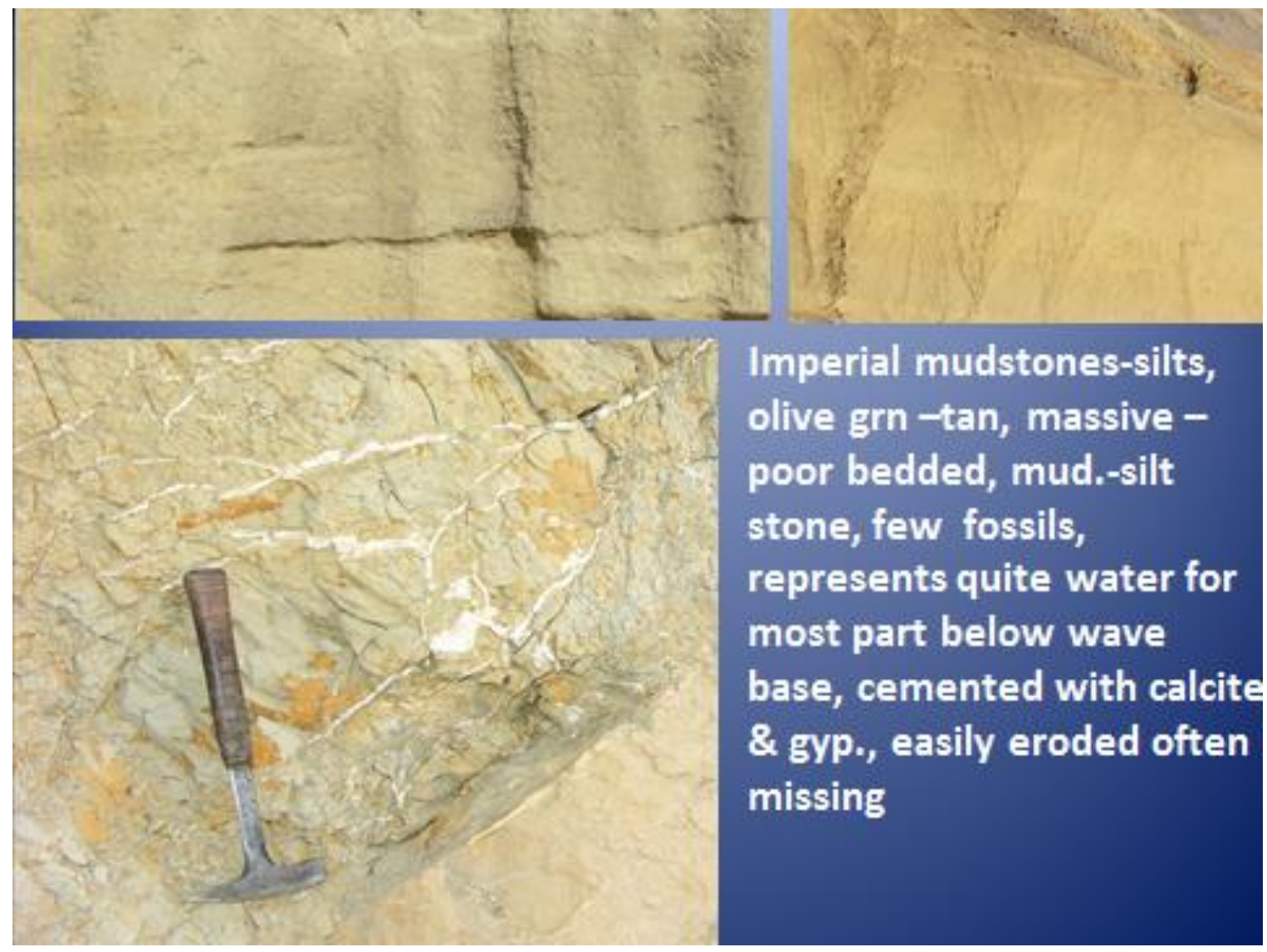

The mudstones in the T-R sequences are impossible to distinguish from each other without their accompanying sandstones and basal conglomerates. The mudstones of the Viejo T-R sequences even look like the mudstones of the Deguynos Formation. 
Slide 13

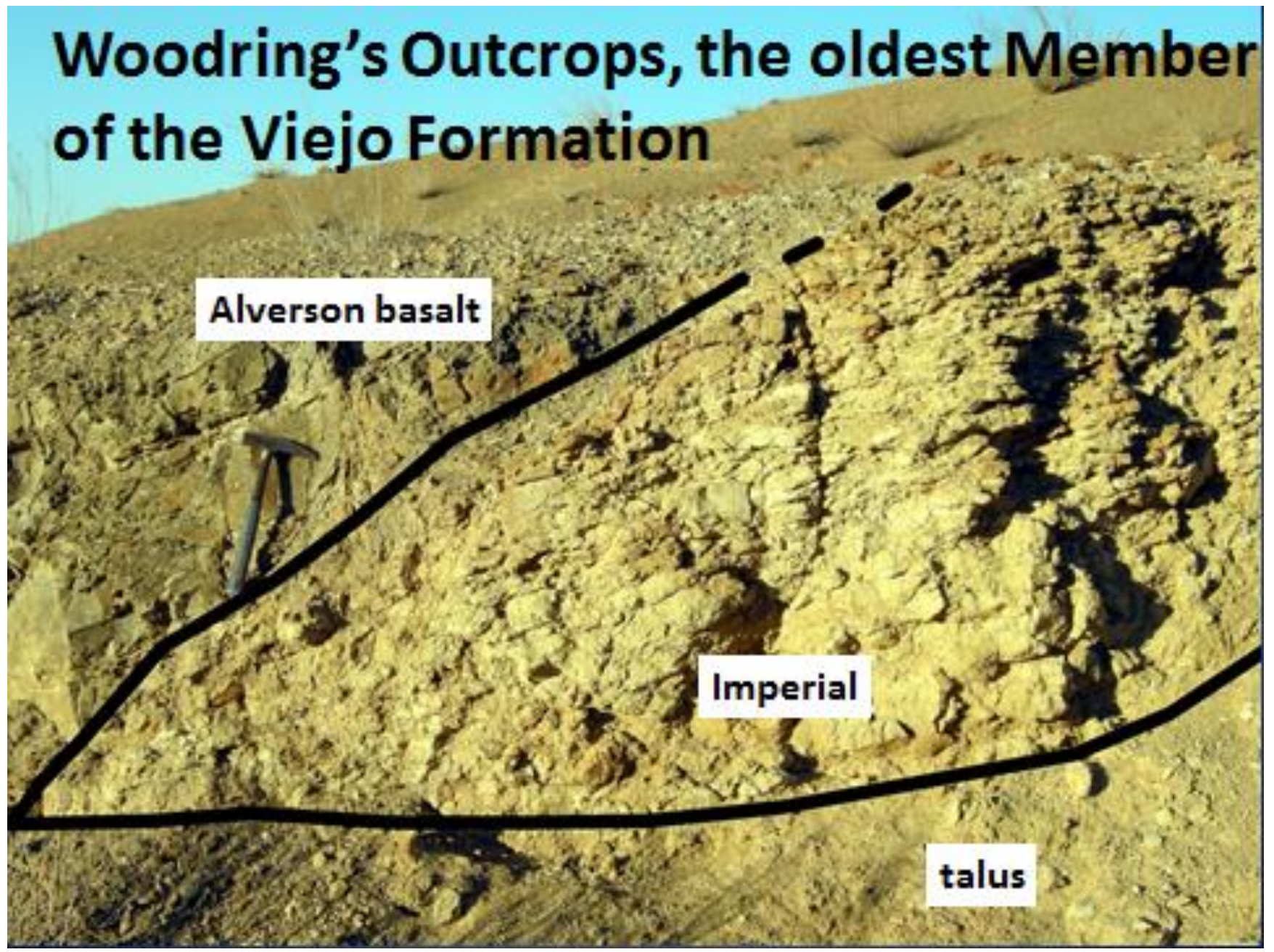

Looking at west side of wash. Woodring (1931) was a USGS geologist who looked at the marine sediments in the Salton Trough during early 1930s. In a report he mentioned finding, in the southern CM, Imperial marine sediments interfingering with basalts of the Alverson Formation. The geologists who have since mapped in Salton Trough have discounted Woodring's observations, including us. While looking for tuffs in the basalts near Bataca Canyon we found his outcrops. They are small and unimpressive outcrops except for the marine fossils they contain. The sediments do not have a bake zone. 
Slide 14

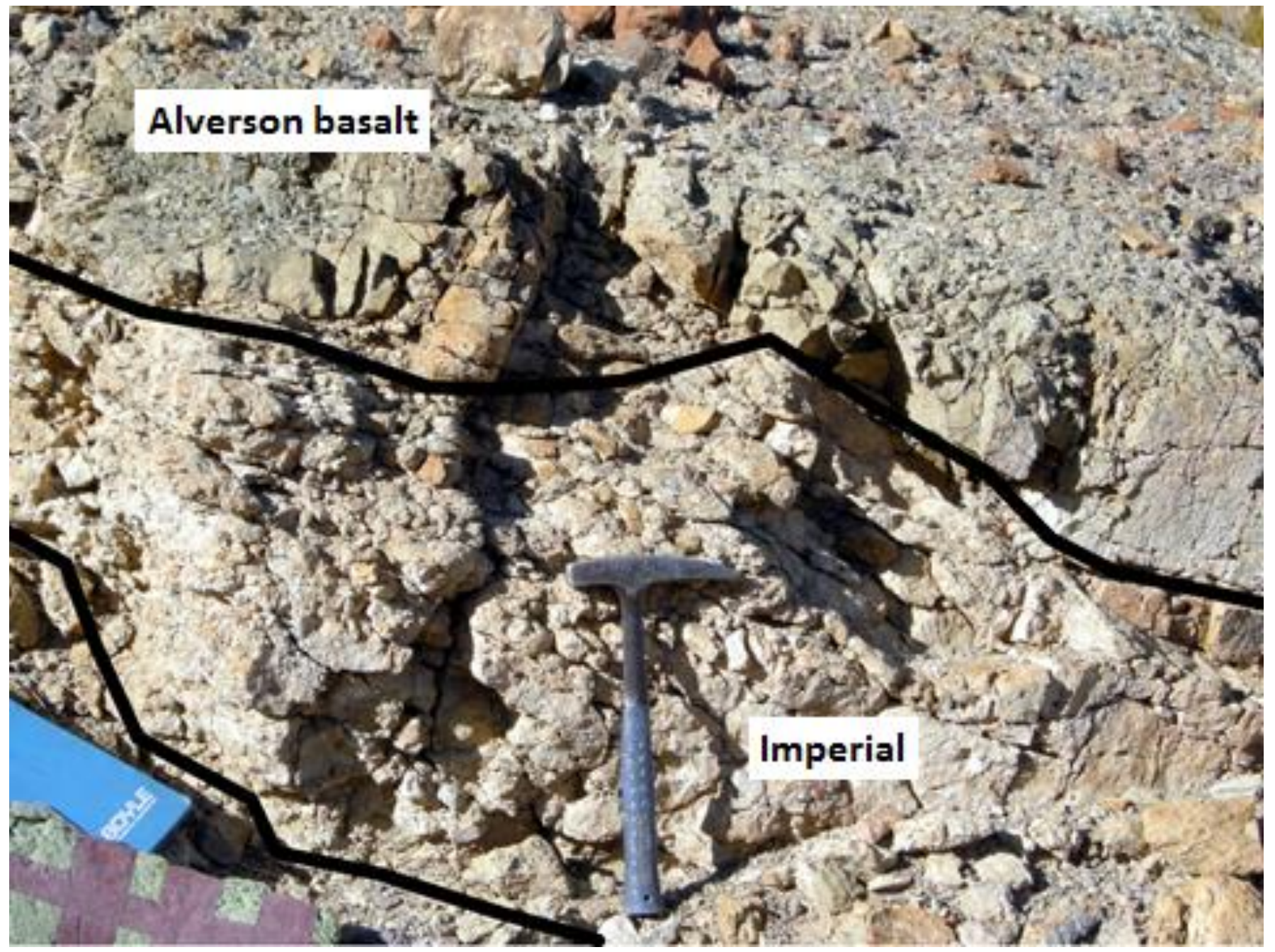

Looking at east side of the wash. Some have tried to explain the interfingering as slumping, but we see no evidence for slumping. The interfingering of Viejo marine sediments with the Alverson indicates that the marine waters (Gulf of California) arrived in the CM earlier than 5.5 Ma of Winker and Kidwell (1996) or 6.3 Ma of Dorsey (2012). 
Slide 15

\section{Simplified Cross Section of Woodring's Outcrops}

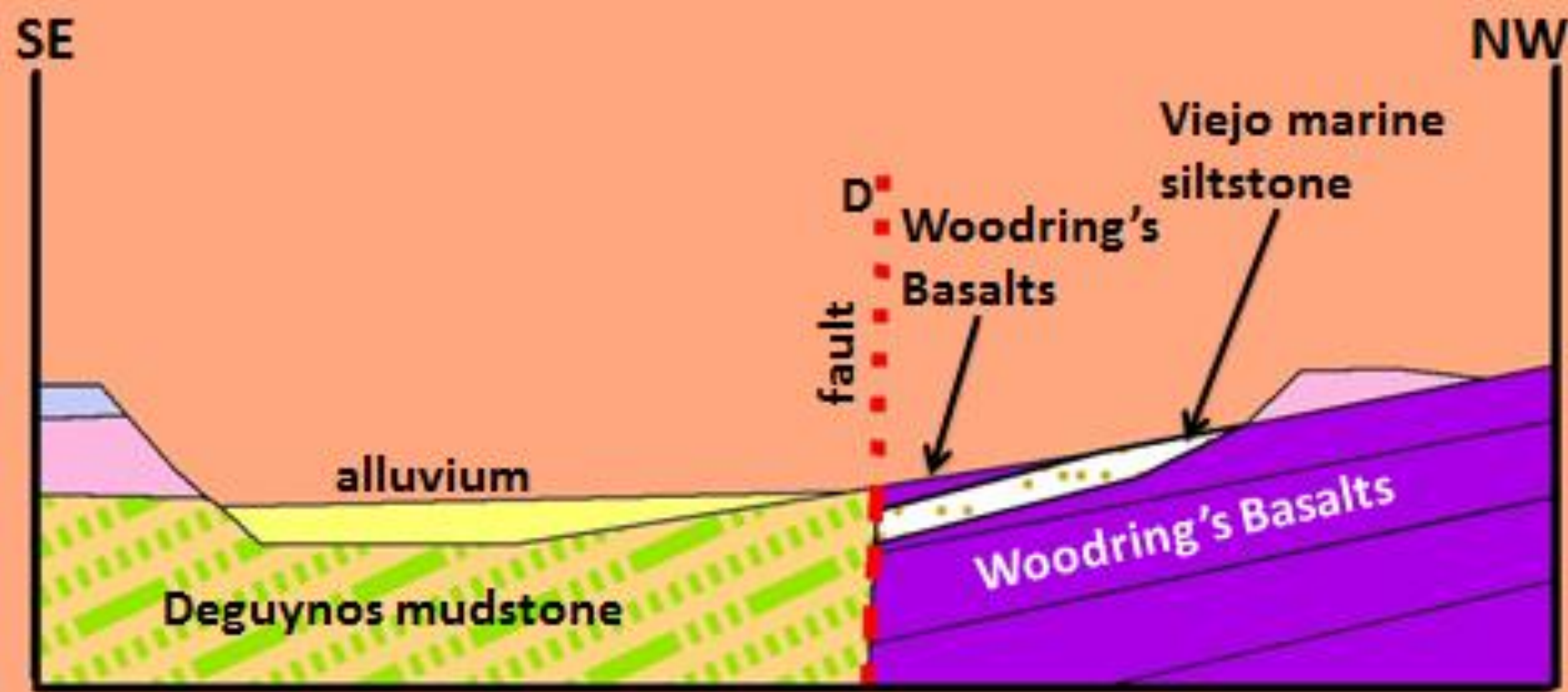

not to scale

This relationship, where the Viejo and the Alverson interfinger, is observed in other locations. 


\section{Small side canyon east of Alverson Canyon}

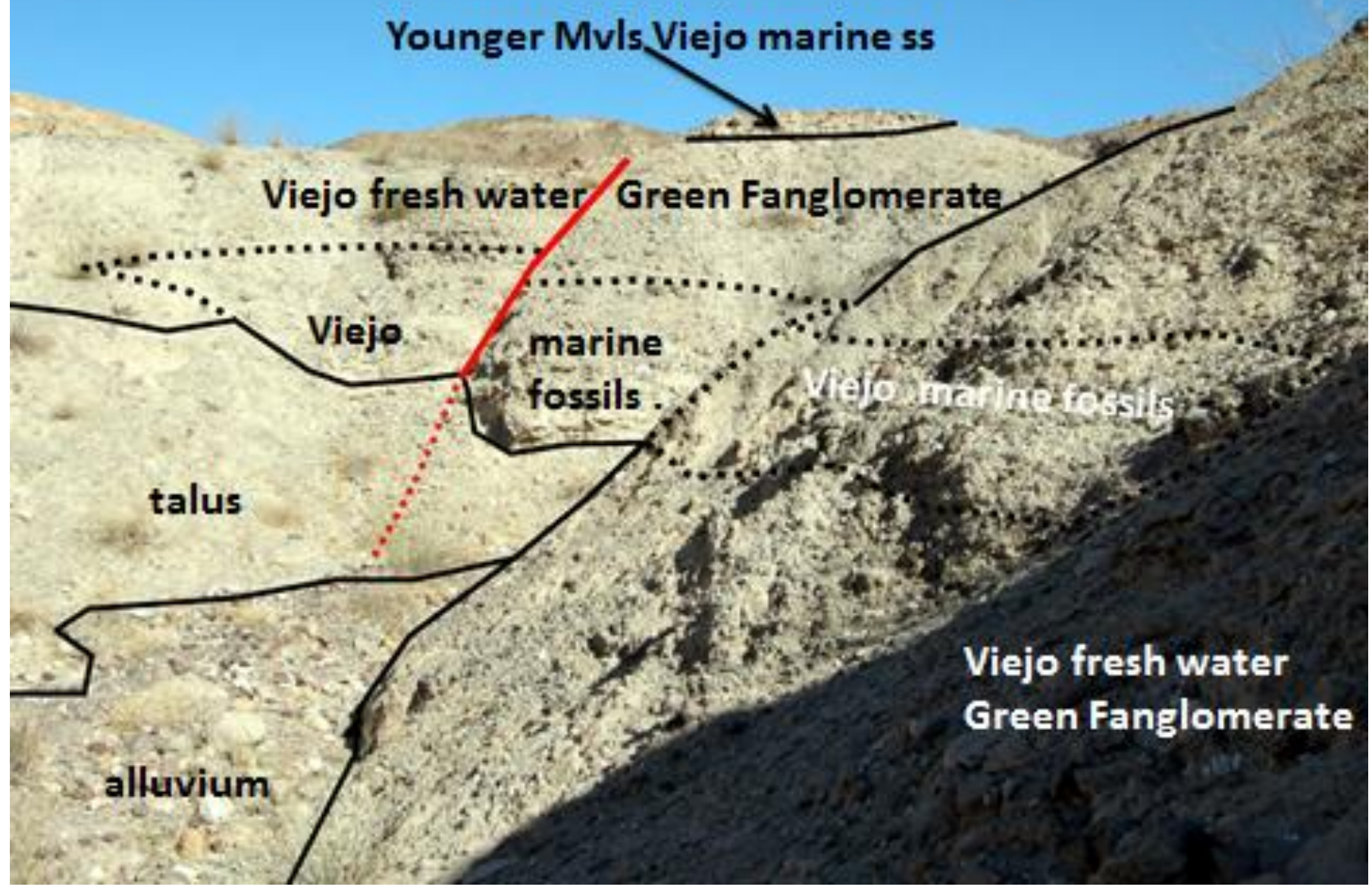

The Green Fanglomerate Member of the Viejo Formation forms the resistant cliffs on the sides of lower Alverson (Fossil) Canyon. Winker and Kidwell's (1996) mapped our Green Fanglomerate as a part of their Garnet Formation. In a small east running side canyon, Viejo marine sediments can be found interfingering with the Green Fanglomerate. This outcrop has not been seen by the professors or students that have mapped in the CM because the corals that are in place are undisturbed. Bell (1980) also recognized, a short distance to the south and east, an Imperial marine unit interfingering with the Green Fanglomerate. Dibblee (2003) included the Green Fanglomerate in his Imperial. 
Slide 17

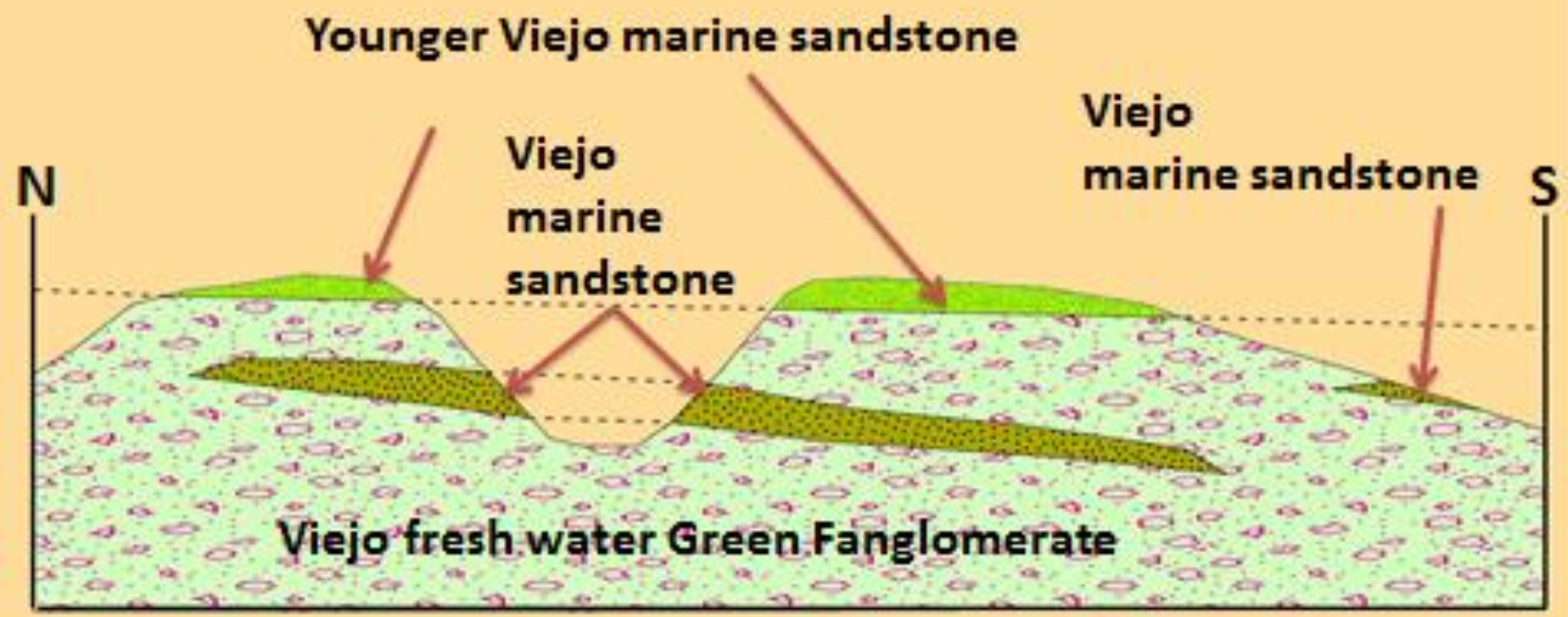

\section{Simplified Cross Section of east running side canyon (not to scale)}

In the area of the east-running side canyon, the Green Fanglomerate rests unconformably on the Alverson Formation. The Green Fanglomerate can be mapped east along the southern $\mathrm{CM}$ as far as the Gypsum Canyon area. 


\section{Slide18}

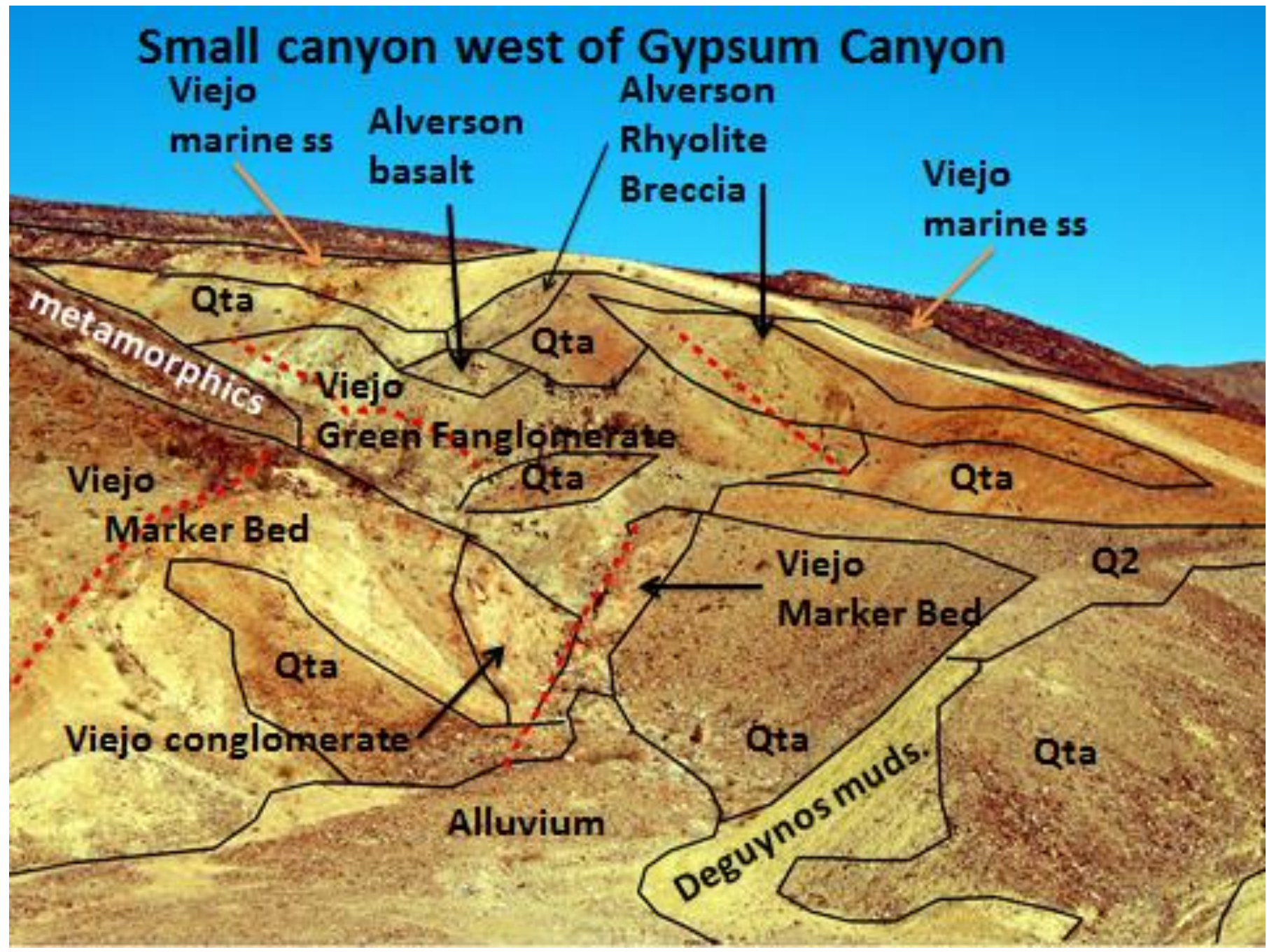

The Green Fanglomerate can be found in a small canyon west of Gypsum Canyon, deposited unconformably on metamorphic and igneous rocks of the southern $\mathrm{CM}$. There are no marine fossils in this outcrop of the Green Fanglomerate, but the fanglomerate is capped by Alverson volcanics. This is the second outcrop of Viejo sediments that interfinger with the $17.1 \mathrm{Ma}$ aged Alverson Formation. Qta-talus. Red dashed lines are faults. Q2- terrace \# 2. 
Slide 19

\section{Simplified Cross Section west of Gypsum Canyon}

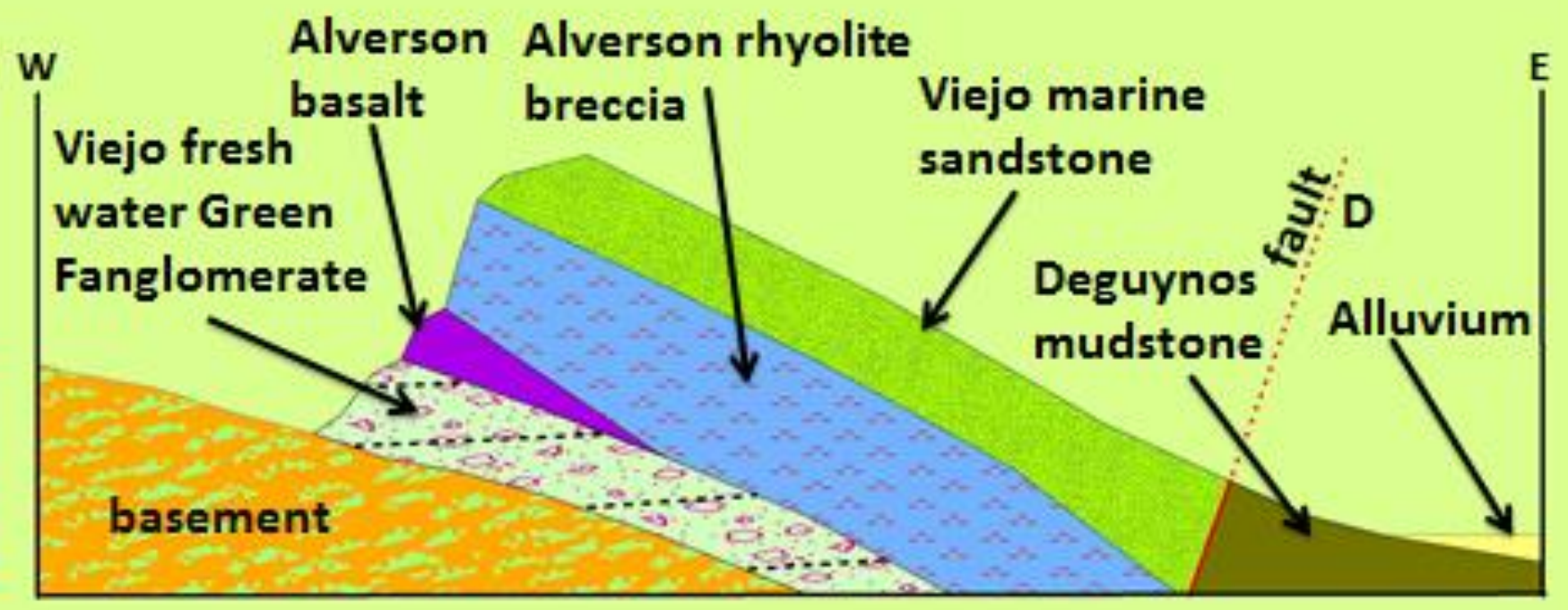

\section{(not to scale)}

The Alverson Formation units that are found under Green Fanglomerate to the west in the Alverson (Fossil) Canyon area are missing in the Gypsum Canyon area. 
Slide 20

\section{Youngest Viejo Formation Member}

\section{Dark Cuesta Member} (DCM) south side of Coyote Mountains

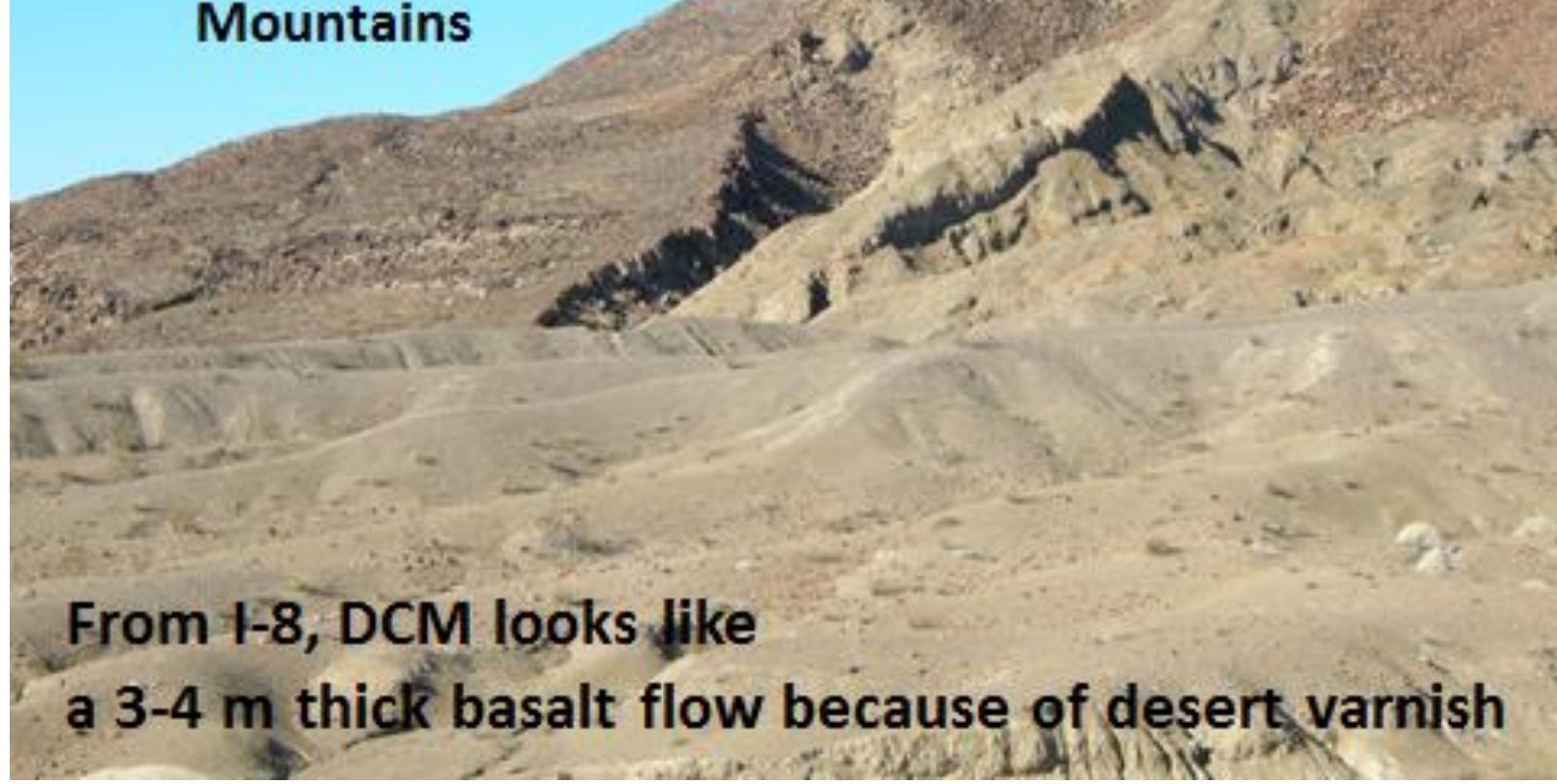

The reason the DCM looks like a basalt flow from Interstate 8 is the desert varnish on its surface. The desert varnish normally does not form on Imperial Group marine sandstones or basal conglomerates. This particular well cemented conglomerate has clasts that are well rounded, quartz rich, metamorphic and granitic pebbles (hard rocks). There are a few volcanic clasts, but no marble or schist clast (soft rocks). The clasts are from older Viejo basal conglomerates that have been reworked to well-rounded pebbles. The matrix of this conglomerate is a granitic arkose with granitic lithic fragment. Surface weathering of the granitic matrix and lithic fragments produced the desert varnish. The bottom of the unit has a flat. The lack of fresh debris from the CM in this particular T-R sequence indicates that the $\mathrm{CM}$ were buried by older Viejo members. Bell (1980) was the first to recognize this unit. 
Slide 21

\section{Dark Cuesta marker bed,} narrow part of Alverson Canyon

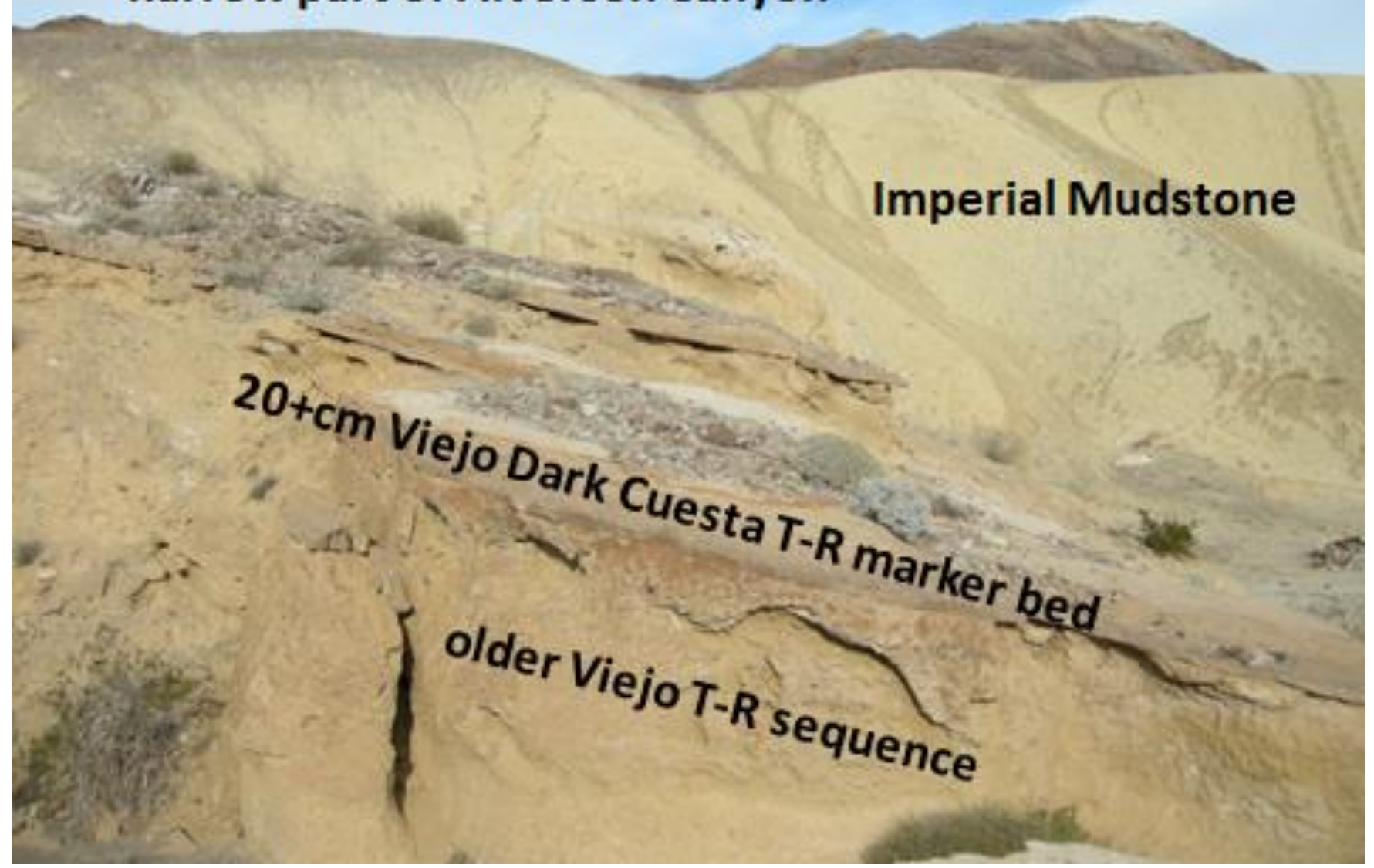

The DCM can be followed west to the Alverson Canyon area where it makes a very-good marker bed. It is much thinner, but still has a flat bottom. We believe that the change from the usual calcarenite matrix to granitic arkose is an indication of the source rock for the arkosic granitic matrix of the DCM basal conglomerate. We have not found similar arkosic units up or down the section. We believe that the source of the matrix is not located in the CM. The increase in the volume and immaturity of basal conglomerate matrix indicates to us that the source rock of the DCM was a run out debris flow that originated from an unknown granitic terrain. 
Slide 22

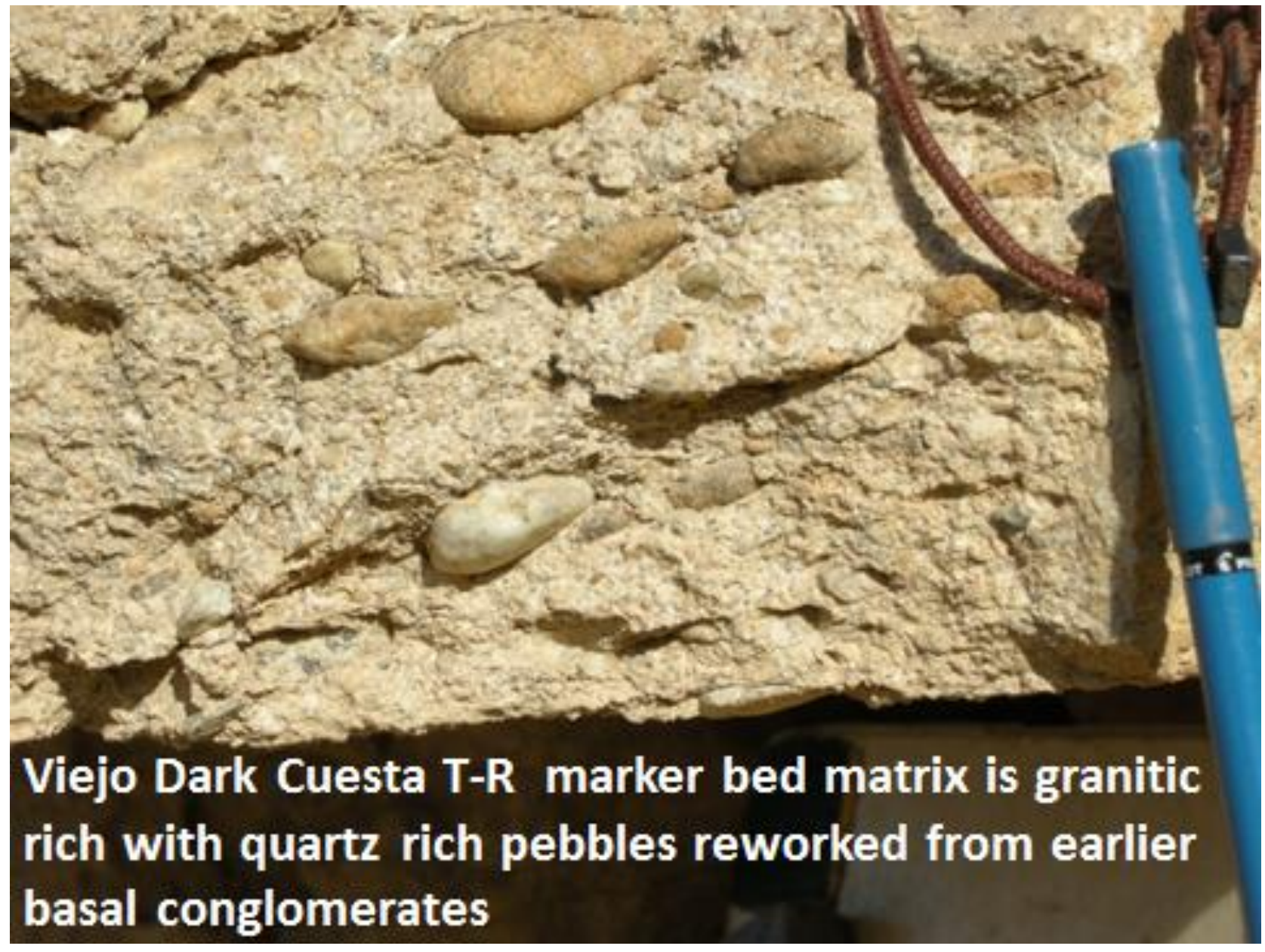

In this close-up of the DCM the quartz rich pebbles show near shore imbrication. Note the quartz rich granitic arkosic matrix with weathered feldspars and the flat bottom. 
Slide 23

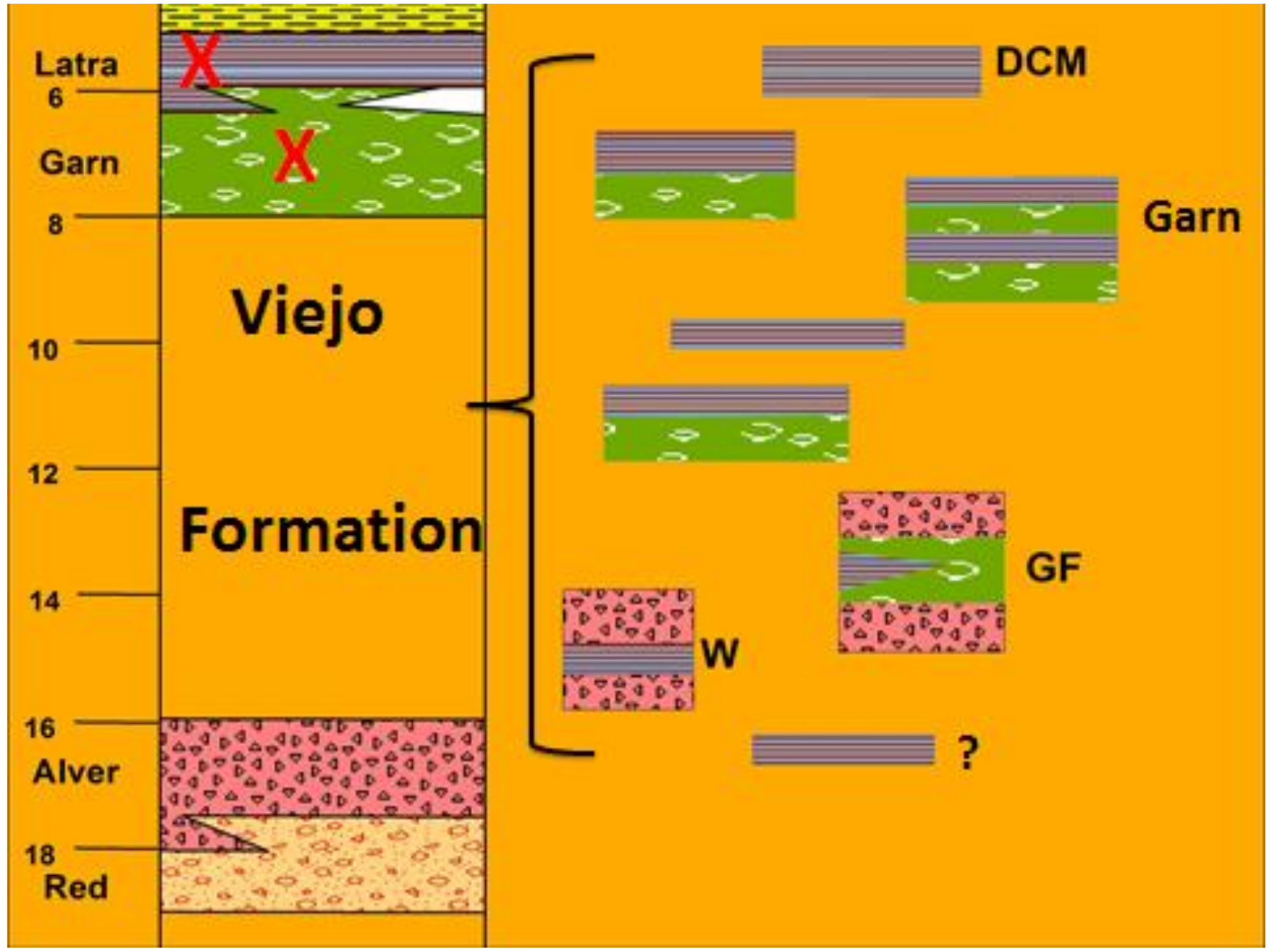

We believe that we have made a compelling argument for replacing Winker and Kidwell's (1996) Latrania and Garnet Formation in the CM with the Viejo Formation. The Viejo formation is not only a better fit for the geology we have mapped in the CM but fills in a avoid that existed in the sedimentary record for the structural basin that is found on the southwestern and southern side of the CM. The Viejo would be unconformably below the Deguynos Formation which is widely deposited in the Salton Trough. Christensen's Garnet Formation would become a member of the Viejo Formation. We are continuing our mapping of the $\mathrm{CM}$ and currently looking for tuffs to help us with age control. DCM- Dark Cuesta T-R Member(youngest). Garn-Christensen's Garnet Formation and our Garnet T-R Member. GF-Green Fanglomerate T-R Member. W-Woodring T-R Member, 


\section{ACKNOWLEDGMENTS}

Thanks to the following:, Bill Elliott, Tony Carrasco, Mike Hart, Ann Bykerk-Kauffman, Eric Frost, Stephen Schellenberg, Monte Marshall, Gordon Gastil, Gary Axen, Larry Busch, Charles Winker, Jerry Treiman, Jon Spencer, John Prall, and Jim Senn.

\section{REFERENCES}

Bell, Patricia J., 1980, Environment of Deposition, Pliocene Imperial Formation Southeast Coyote Mountains, Imperial County, California: M.S. thesis, San Diego State University.

Bykerk-Fauffman, A., 2015, Field Trip B: Fossil Canyon to Gypsum Canyon. In Wagner, R., ed, Geology of the Coyote Mountains, southern California: San Diego Association of Geologists, p. 31-42.

Christensen, A. D., 1957, Part of the geology of the Coyote Mountains area, Imperial County, California: Unpublished M.S. thesis, University of California at Los Angeles, 188p.

Dibblee, T. W., 1954, Geology of the Imperial Valley region, California, in Jahns, R. H., ed., Geology of southern California: California Division Mines Bulletin, v. 170, p. 21-28.

Dibblee, T. W., 2003, Geology of the Coyote Mountains, Imperial and San Diego Counties, California, In, M.L. Murbach and M.W. Hart (eds.), Geology of the Elsinore Fault Zone, San Diego Region: San Diego Association of Geologist, San Diego, South Coast Geological Society, Santa Ann, California, p.117-123

Dorsey, R.J. (2012), Earliest delivery of sediment from the Colorado River to the Salton Trough at 5.3 Ma: Evidence from Split Mountain Gorge. In: Reynolds, R.E. (ed.) Searching for the Pliocene: southern exposures. Proceedings of the 2012 Desert Symposium, p. 88-93.

Morgan, G. J., and Morgan, J. R., 2005, The Painted Gorge Wash Fault: recent leftlateral faulting, east side Coyote Mountains, Imperial County, California: Bloom, D. M., ed. Geology and history of southeastern San Diego County, California, San Diego Association of Geologists, p.189-204. 
Morgan, G. J., and Morgan, J. R., 2015, Overview of the Geology of the southern Coyote Mountains, Salton Trough, Imperial County, southern California. In Wagner, R., ed, Geology of the Coyote Mountains, southern California: San Diego Association of Geologists, p.77-87.

Morgan, J. R., Morgan, G. J. and Pecha, M., 2012, U/Pb dating of tuffs from the Alverson Volcanics in the Fossil Canyon and Painted Gorge areas of the Coyote Mountains, western Salton Trough, California, GSA, Abstract and Programs, Vol. 44 , No. 3 , p. 22

Morton, P. K., 1977, Geology and mineral resources of Imperial County, California: California Division of Mining and Geology, County Report No.7.

Ruisaard, C. I., 1979, Stratigraphy of the Miocene Alverson Formation, Imperial County, California: Masters of Science Thesis, San Diego State University, 125p.

Winker, C. D., and Kidwell, S. M., 1996, Stratigraphy of a marine rift basin: Neogene of the western Salton Trough, California, in Abbott, P. L., and Cooper, J. D., eds., Field Conference Guidebook and Volume for the Annual Convention: San Diego, California, American Association of Petroleum Geologists, Pacific Section, p. 295336.

Woodring, W. P., 1931, Distribution and age of the Tertiary Deposits of the Colorado Desert: Carnegie Institution of Washington Publication 148, p. 1-25 